\title{
Experiments on the spread of colds
}

\section{Studies in volunteers with coxsackievirus A21}

\author{
By F. E. BUCKLAND, M. L. BYNOE AND D. A. J. TYRRELL \\ M.R.C. Common Cold Research Unit, Harvard Hospital, Salisbury, Wilts.
}

\section{(Received 16 November 1964)}

In the first paper of this series (Buckland \& Tyrrell, 1964) we described experiments in which tracers were used to follow the dispersal of secretions from the upper respiratory tract of volunteers without colds. To amplify these studies we have performed further experiments in volunteers who had been given colds, and these experiments are described in the present report.

Coxsackievirus A 21 has now been isolated in a number of different outbreaks of disease, first of all in California by Lennette, Fox, Schmidt \& Culver (1958), later in Great Britain by Pereira \& Pereira (1959) and more recently in North Carolina by Johnson, Bloom, Mufson \& Chanock (1962). In each outbreak it was associated with mild upper respiratory infections diagnosed as common colds or pharyngitis. Volunteers at this Unit were successfully infected by intranasal inoculation and developed typical common colds (Parsons, Bynoe, Pereira \& Tyrrell, 1960); more severe illnesses were also observed by Spickard, Evans, Knight \& Johnson (1963) in volunteers to whom they gave larger doses of virus. Coxsackievirus A21 can therefore be regarded as a 'cold virus', although it is an uncommon cause of the disease.

We chose to use coxsackievirus A 21 in these experiments because it has several practical advantages over other viruses which also cause colds. For example, it may be readily and accurately titrated in human diploid cells, and it is stable on storage at $-20^{\circ} \mathrm{C}$. Since antibodies are uncommon in the general population few volunteers are immune to infection.

We recognize that this virus does not seem to spread as readily as do other agents which cause the common cold-this is the apparent explanation for its being usually found in the congested conditions of training camps for the Services rather than among civilians. Nevertheless, we chose it for our initial experiments in preference to viruses such as the myxoviruses, which are unstable and therefore difficult to titrate accurately, and to the rhinoviruses to which a large number of our volunteers possess antibodies.

This paper reports experiments in which we attempted to find: $(a)$ where the concentration of virus was highest in infected volunteers and therefore by what route virus was most likely to leave the body, $(b)$ the area of the upper respiratory tract which was most susceptible to infection, and $(c)$ the means by which the virus might most readily initiate an infection under natural conditions. 


\section{MATERIALS AND METHODS}

The virus used was obtained from a swab collected from a patient in the R.A.F. (Parsons et al. 1960). This virus was given to volunteers, and pooled nasal secretion from them was used as inoculum in some experiments. In others, the virus was passed into human amnion cultures and then into human embryo kidney cultures and the fluids from the latter were used as the inoculum.

\section{Titration of viruses}

The specimens obtained from volunteers were titrated by inoculating serial dilutions of virus into tube cultures of human diploid cell strains, which were highly sensitive to coxsackievirus A 21 (Brown \& Tyrrell, 1964). The cells were maintained in Eagle's medium containing $2 \%$ calf serum, and were rotated in a roller drum. Tenfold dilutions of virus were inoculated into groups of three tubes in most instances. When more accurate results were required $3 \cdot 16$-fold dilutions were inoculated into groups of five tubes. Fifty per cent infectivity end points (TCD 50) were estimated by the method of Reed \& Muench (1938).

\section{Antibody titrations}

Antibody against coxsackievirus A21 was estimated by haemagglutination inhibition tests using the techniques of Takátsy (1955). In most experiments the red cells used were human group $\mathrm{O}$ cells from cord blood and were selected because they were highly sensitive to the virus agglutinin. To obtain the highest titre the virus was usually prepared by the inoculation of tube or bottle cultures of human embryo kidney cells. The fluids were harvested when an advanced cytopathic effect was observed and were stored at $-70^{\circ} \mathrm{C}$. until required. Serial dilutions of inactivated serum were made in phosphate buffered saline $\mathrm{pH} 7 \cdot 1$. To each dilution were added, in an equal volume of saline, four haemagglutinating units of virus. After incubation at room temperature for $30 \mathrm{~min}$. a further volume of $1 \%$ red cells was added and the mixtures were allowed to settle at $4^{\circ} \mathrm{C}$. The titre was taken as the highest dilution giving complete inhibition of haemagglutination.

The antibody levels determined by haemagglutination inhibition were checked by neutralization tests on fifteen sera, using about 100 TCD 50 of virus, and holding the mixture of serum and virus at $37^{\circ} \mathrm{C}$. for $2 \mathrm{hr}$. and then at $4^{\circ} \mathrm{C}$. for $12 \mathrm{hr}$. Of eleven sera with a titre of four or less by the H.I. test, only one contained detectable neutralizing antibody at a titre of 4 . Neutralizing antibody was found in all four sera with an H.I. titre greater than 4.

\section{Inoculation of volunteers}

The standard method of inoculation at this Unit was used in the early experiments. Volunteers lay on their backs with the neck extended, and $0.5 \mathrm{ml}$ of inoculum was instilled into each nostril. The patient remained on his back for $1 \mathrm{~min}$. before getting up and refrained from blowing his nose for the next hour. Other methods of inoculation will be described later in the text. 


\section{Selection and observation of volunteers}

Volunteers of both sexes aged between 18 and 50 years were observed and cared for in isolation as described by Andrewes (1948). Nasal washings were collected daily from each volunteer for at least 4 days after inoculation and a specimen of serum was collected just before inoculation and again 3 weeks later, after the volunteer had left the Unit. In certain experiments swabs were collected instead of nasal washings. A final concentration of $2 \%$ bovine plasma albumin was added to all clinical specimens before they were frozen. Volunteers were classified as 'infected' if virus was recovered from one or more nasal washings; in many of these subjects a rising antibody titre was also detected.

\section{RESULTS}

The first experiments, summarized in Table 1 and Fig. 1, were performed in order to measure the concentration of virus excreted during an experimental infection. One group of volunteers received tissue-culture-passed virus and the

Table 1. Recovery of virus during a period of 6 days from ten volunteers who were inoculated with nasal drops

$\begin{array}{ccccccc}\begin{array}{c}\text { Source of } \\ \text { virus given }\end{array} & \begin{array}{c}\text { Dose } \\ \text { TCD 50 }\end{array} & \begin{array}{c}\text { Nasal } \\ \text { washings }\end{array} & \text { Garglings } & \text { Saliva } & \text { Faeces } \\ \text { Tissue culture } & 750 & 6 / 6^{*} & 4 / 6 & 2 / 6 & 5 / 6 \\ & & 21 / 36 & 7 / 36 & 5 / 36 & 6 / 36 \\ \text { Source of } & \text { Dose } & \text { Nose } & \text { Throat } & & \\ \text { virus given } & \text { TCD 50 } & \text { swab } & \text { swab } & \text { Saliva } \\ \text { Nasal washing } & 8 & 4 / 4 & 4 / 4 & 2 / 4 \\ & & 15 / 24 & 14 / 24 & 4 / 24\end{array}$

* The upper row of fractions shows the proportion of volunteers giving a positive result and the lower row shows the proportion of specimens giving a positive result

other group received nasal washings of virus which had never been passed through tissue culture. All the volunteers became infected, but it may be seen that virus was recovered most frequently from the nasal washings and least frequently and in the lowest concentration from the saliva and faeces (Table 2 and Fig. 1). The mean titre of virus in nasal secretions was at least 100-fold higher than that in the throat secretion or saliva, and this was consistent with its being produced in the nose and overflowing into the throat. The concentration ratios were similar to those seen in experiments in which spores were slowly discharged into the nose, and their concentrations in the throat and saliva were followed (Buckland \& Tyrrell, 1964). It can be seen from Fig. 1 that there were wide variations in the amount of virus excreted by different volunteers. These differences were not closely correlated with the severity of the disease from which they suffered. The upper and lower halves of Table 1 and the right and left halves of Fig. 1 also show 
that the results were very similar, whether the virus administered had been passed in tissue cultures or not. In one set of experiments the concentration of respiratory secretions in a washing was assumed, and in the other the weight of secretion taken up by the swab was measured. It was possible that a swab might have irritated the nose and changed the character of the secretion or retained virus; on the other hand, the estimated amount of secretion in the washing might have been wrong. Since the results were so similar despite the variations in procedure we do not believe that serious technical errors occurred.
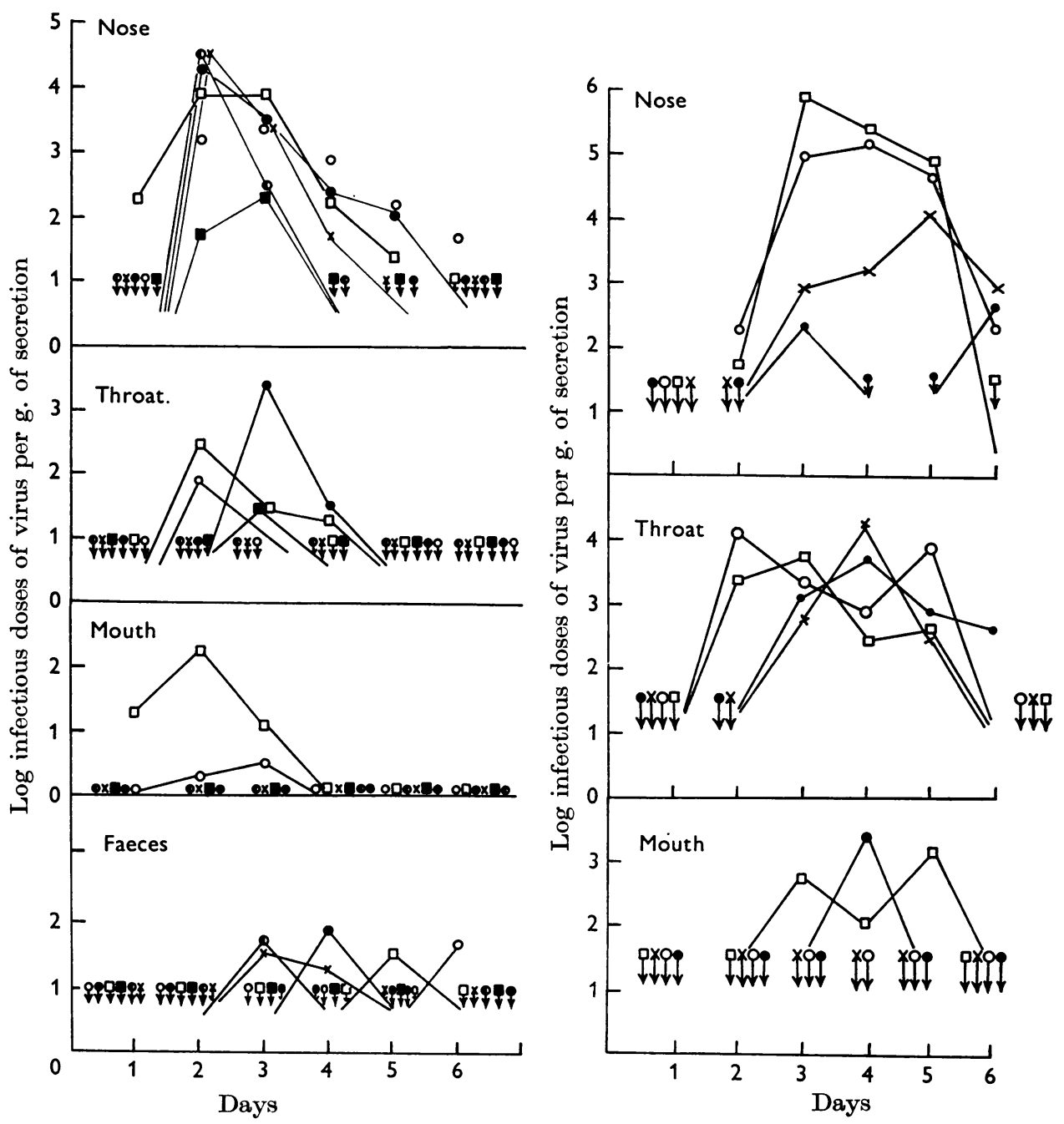

Fig. 1. Two experiments to measure the concentration of virus in subjects with colds due to coxsackievirus A21. The left-hand panel summarizes the results with six volunteers in whom the virus was recovered from the nose and throat by washings. Virus was only occasionally found in the saliva and faeces. Most virus was found in the nose (see also Table 2). The right-hand panel shows the results with four volunteers from whom the virus was collected by swabbing. The results are similar but one volunteer had little virus in the nose and a relatively large amount in the throat and saliva. 
The inoculation of virus by various routes

When virus is administered in $1 \mathrm{ml}$. of saline it rapidly spreads over all the nasal mucous membranes and the pharynx, and one cannot be sure in what area infection is initiated. We therefore prepared experiments in which the virus was administered in various ways.

Table 2. Estimated mean concentration of virus during infection of six volunteers inoculated with 750 TCD 50 of virus passed in tissue culture

$\begin{array}{ccccc}\begin{array}{c}\text { Day } \\ \begin{array}{c}\text { after } \\ \text { inoculation }\end{array}\end{array} & \begin{array}{c}\text { Nasal } \\ \text { secretion* }\end{array} & \begin{array}{c}\text { Throat } \\ \text { secretion* }\end{array} & \text { Saliva } & \text { Faeces } \\ 1 & 2.2 & <0.5 & 0.9 & <0.5 \\ 2 & 4.7 & 2.4 & 1.3 & <0.5 \\ 3 & 4.6 & 2.5 & 1.0 & 1.9 \\ 4 & 3.0 & 2.3 & <0.5 & 2.0 \\ 5 & 2.6 & <0.5 & <0.5 & 1.8 \\ 6 & 2.1 & <0.5 & <0.5 & 1.8\end{array}$

* Estimated from the titre of nasal washings and garglings assuming that nasal washings contained $10 \%$ nasal secretion and garglings $10 \%$ of throat secretion.

\section{Table 3. Infectivity of virus given by various routes}

\begin{tabular}{llccc}
\multicolumn{1}{c}{ Method } & Route & Dose TCD 50 & Infected & With colds \\
Swab & Hand/nose & 1500 & $0 / 4$ & $0 / 4$ \\
Swab 0.01 ml. & Nasal septum & 16 & $4 / 4$ & $4 / 4$ \\
& Conjunctiva & 16 & $4 / 4$ & $3 / 4$ \\
& Oropharynx & 16 & $0 / 6$ & $0 / 6$ \\
& Oropharynx & 280 & $1 / 6$ & $0 / 6$ \\
Drop 0.05 ml. & Nasopharynx & 280 & $2 / 8$ & $0 / 8$ \\
& Nasal septum & 8 & $5 / 6$ & $5 / 6$ \\
& Nasal septum & 0.8 & $3 / 4$ & $4 / 4$ \\
& Nasal septum & 0.08 & $0 / 5$ & $0 / 5$
\end{tabular}

With the exception of one subject in row 8 of this table the volunteers classified in Tables 3 and 5 as 'with colds' were always also 'infected'.

Table 3 shows that no volunteers became infected when a large dose of virus was rubbed on to their index fingers and thence on to the outside of the nose and the external nares. The volunteers carried on with their normal day's activities for 4 or $5 \mathrm{hr}$. without washing their hands and ate at least one meal, but nevertheless none of them became infected. We also studied the effect of placing the virus in different parts of the upper respiratory tract by gently rubbing a swab soaked in virus inoculum on to the posterior wall of the pharynx, the nasopharynx, the nose and the inferior fornix of the conjunctiva. It was estimated that roughly 0.01 $\mathrm{ml}$. of the inoculum was rubbed off on the mucous membranes. Virus put in this manner on to the nasal septum or the conjunctiva infected in low dosage in every instance, whereas the same or even larger doses were practically non-infectious when placed on the pharynx, and only slightly more infectious when put on to the the membranes of the naso-pharynx. The virus used in these experiments was 
'natural', that is, it had not been passed through tissue culture, but it was felt that the rubbing of the swab was rather unnatural, since viruses probably reach the mucous membrane in small droplets or dry particles; the trauma of rubbing might have increased the susceptibility of the mucosa as it apparently does for adenovirus (Huebner et al. 1955; Bell et al. 1956). Therefore, in a further series of experiments an attempt was made to estimate the minimum amount of virus required to infect the nasal mucous membrane as a small drop. In these experiments $0.05 \mathrm{ml}$. of virus suspension was placed under direct vision in the nose, half on each side of the anterior part of the nasal septum, using a fine capillary pipette. It can be seen from Table 3 that rather less than one tissue culture infectious dose infected most of the volunteers when administered in this way.

\section{Exposure of volunteers to airborne virus}

It is probable that, unlike the small drops used in this experiment, inhaled particles are not moist, are smaller than $0.025 \mathrm{ml}$. in volume and are trapped not so much on the anterior nasal septum as on the anterior end of the turbinates

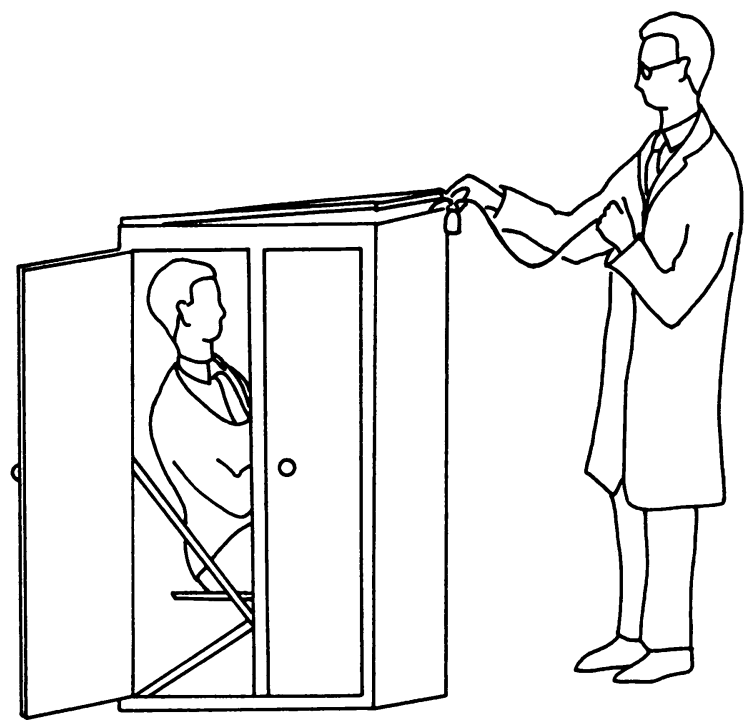

Fig. 2. The cupboard used for inoculating volunteers with sprayed virus. The volunteer sat inside with his eyes closed. In an actual experiment the door would be closed. The lid has been slightly lifted for the moment so that the spray nozzle is in position to deliver a 'puff'. The impinger or preimpinger samplers are placed by the subjects left cheek.

(Negus, 1958). We therefore felt that these experiments should be completed by trying to measure the minimum infectious dose of virus administered as an aerosol which resembled a natural sneeze. The method used was developed from one described in an earlier paper (Buckland \& Tyrrell, 1964). A simple apparatus, a 'sneeze cupboard', was constructed, the essentials of which are shown in Fig. 2. The subject sat in a chair inside a wardrobe of which the top had been replaced by a transparent lid which would admit light and allow observation of the volunteer. During an experimental exposure both doors of the wardrobe were closed. 
The virus suspension was sprayed in as shown using a special spray which produced droplets of the same size range as those produced by a sneeze (Buckland \& Tyrrell, 1964). An impinger and preimpinger containing $2 \%$ calf serum in Eagle's medium as a collecting fluid stood alongside the volunteer's head and sampled air at $11 \mathrm{l} . / \mathrm{min}$. while he was sitting there. Experiments were first done using a suspension of Bacillus mycoides spores as an inert tracer (Buckland \& Tyrrell, 1964); these showed that the level of exposure could be kept to within a range of about two-fold. The persistence of spores in the air of the apparatus is shown in Table 4; clearly most of the coarser droplets are collected within the first few minutes of sampling. In order to administer virus and measure its inactivation in the aerosol, mixtures of virus and spore suspension were sprayed and the volume of spray fluid collected in the sampler was estimated by the spore count.

Table 4. Recovery of spores after spraying about $10^{6}$ spores into 'sneeze' cupboard

\begin{tabular}{ccccc} 
Time of sample & \multicolumn{3}{c}{ Spores recovered in 1 min. from 11 1. of air by } \\
after spray & Preimpinger & $\%$ & Impinger & $\%$ \\
1st min. & 12,000 & 47 & 7,400 & 34 \\
2nd min. & 5,000 & 19 & 4,000 & 18 \\
3rd min. & 3,600 & 14 & 4,600 & 21 \\
4th min. & 2,700 & 11 & 2,800 & 13 \\
5th min. & 2,200 & 9 & 3,000 & 14 \\
Total & 25,500 & & 21,800 &
\end{tabular}

The preimpinger sampler collects particles of the size range trapped in the upper respiratory tract while the impinger collects smaller particles which are trapped in the lower respiratory tract.

Tissue culture fluid containing $2 \%$ bovine plasma albumin was sprayed in two experiments and nasal washings were sprayed in one. Both virus and spores were recovered on the impinger and preimpinger. The results were consistent. The titre of virus recovered in the preimpinger was lower than that expected from the spore count by 0.44 to $1.12 \log _{10}$ units and the mean reduction in five estimates was 0.6 unit (fourfold). In impingers the titres were 1.45 units lower than expected. Control experiments showed that no virus was inactivated in the sprayer or the samplers. We therefore concluded that $75 \%$ of the virus sprayed as coarse droplets likely to be trapped in the nose was inactivated in the spray, and that $97 \%$ of the virus in the finer droplets was so inactivated.

In order to infect a volunteer the spray was projected into the 'sneeze' cupboard in which he sat for $5 \mathrm{~min}$. following one or more puffs. The volunteer breathed through the nose in most experiments and always kept the eyes closed just as the spray was blown in. A preimpinger sampler containing $2 \%$ calf serum in Hanks's saline was running at about the level of the volunteer's head throughout the time of exposure, and the fluid was assayed both for the virus and for spores of $B$. mycoides which were added to the inoculum as a tracer. The dose of virus administered to each volunteer was calculated from the titre of virus in the impinger fluid. 
In cases where only spores were detected because the concentration of virus was too low the dosage was calculated from the concentration of spores found allowing for inactivation of the virus at the same rate as was found at higher concentrations. The results of several experiments of this type are shown in Table 5. They indicate that airborne virus was infective. The rate of infection was significantly higher if air was drawn in through the nose rather than through the mouth; it is probable

Table 5. Infection of volunteers with virus administered as a spray

\begin{tabular}{|c|c|c|c|c|c|}
\hline \multirow{2}{*}{$\begin{array}{l}\text { Dilution } \\
\text { sprayed }\end{array}$} & \multirow{2}{*}{$\begin{array}{l}\text { Amount } \\
\text { sprayed }\end{array}$} & \multirow{2}{*}{$\begin{array}{l}\text { Volunteer's } \\
\text { type of } \\
\text { breathing }\end{array}$} & \multirow{2}{*}{$\begin{array}{l}\text { Dose } \\
\text { collected } \\
\text { in pre- } \\
\text { impinger } \\
\text { TCD 50 }\end{array}$} & \multicolumn{2}{|c|}{$\begin{array}{c}\text { Proportion of } \\
\text { volunteers }\end{array}$} \\
\hline & & & & Infected & With colds \\
\hline Undiluted & 10 puffs & Mouth closed & 40 & $6 / 6$ & $6 / 6$ \\
\hline Undiluted & 10 puffs & Nose closed & 40 & $3 / 6$ & $2 / 6$ \\
\hline Undiluted & 1 puff & Normal breathing & 4 & $3 / 6$ & $3 / 6$ \\
\hline $1 / 5$ & 1 puff & Normal breathing & 0.8 & $3 / 6$ & $1 / 6$ \\
\hline
\end{tabular}

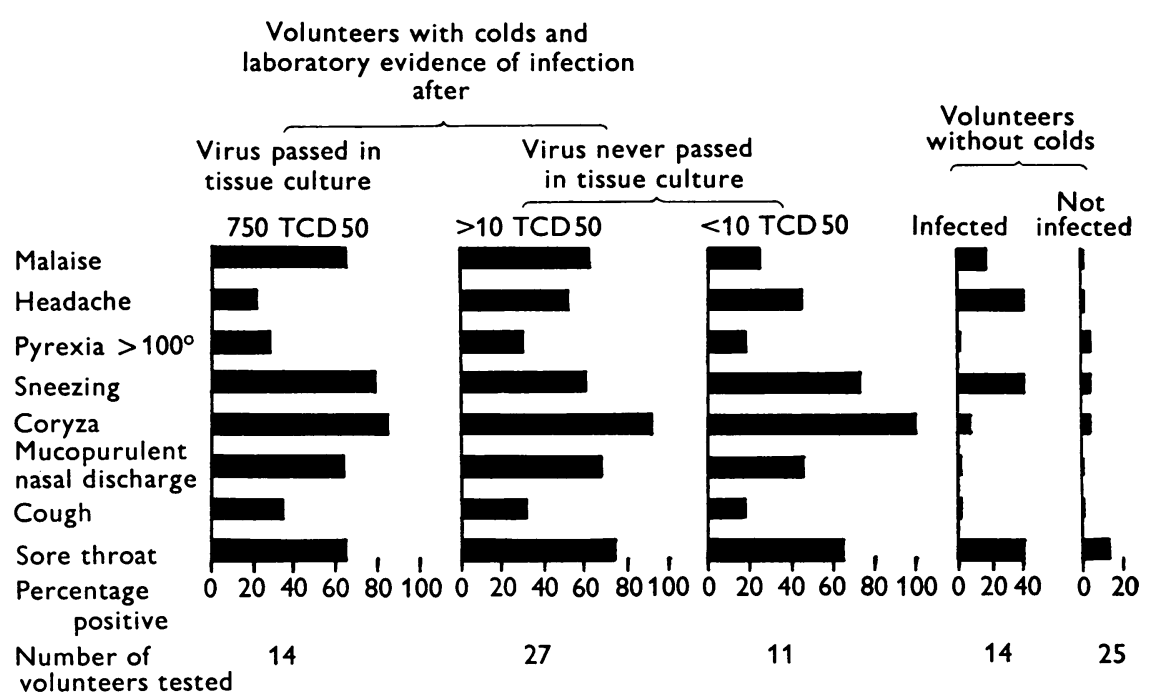

Fig. 3. Proportion of volunteers showing certain symptoms and clinical signs after administration of virus as drops, on swabs or as an aerosol. There were, in addition, three volunteers who developed colds although there was no laboratory evidence of infection.

that some of the aerosol drawn in through the mouth eddied up into the nasal cavities and therefore the result is consistent with the earlier finding that the pharynx is highly resistant to infection. It can also be seen that the amount of airborne virus required to infect a volunteer was about the same as that required when the virus was administered as a drop onto the nasal septum.

\section{Clinical and serological responses to infection}

It can be seen from Tables 3 and 5 that almost all those volunteers who received large or moderate doses of virus (8-160 TCD 50) on the nasal mucous membrane 
became infected. A small proportion of those who were infected with small doses of virus became ill.

The main clinical features of the illnesses produced by various doses of virus are shown in Fig. 3. The clinical symptoms were those of a common cold. They were the same in volunteers who received large doses of virus and those who received small ones, although the former had rather higher fever and more mucopurulent nasal discharge and cough than the latter. The clinical picture was the same by whatever route the virus was administered and the data include the records of volunteers who acted as 'donors' in transmission experiments (see below).

\section{Antibody responses}

Of nineteen volunteers who were infected with small doses of virus ten developed antibody, while of those given larger doses of virus thirty out of thirty-six did so. Eight out of eleven volunteers who had significant antibody levels, i.e. H.I. titre

Table 6. Relation of antibody to infectivity when virus is given by the nasal route

\begin{tabular}{lccccc} 
& & \multicolumn{3}{c}{$\begin{array}{c}\text { Proportion of volunteers with antibody } \\
\text { at time of inoculation } \mathbf{H . I}>\mathbf{4}\end{array}$} \\
\multicolumn{1}{c}{ Virus given } & Dose & $\begin{array}{c}\text { Not } \\
\text { infected }\end{array}$ & $\overbrace{\text { No cold }}^{\text {Infected }}$ & Cold & Total \\
Washing & $0 \cdot 8-10$ & $4 / 6$ & $0 / 6$ & $2 / 8$ & $2 / 14$ \\
Washing & $11-160$ & - & $1 / 4$ & $0 / 16$ & $1 / 20$ \\
Tissue culture fluid & 750 & - & $3 / 5$ & $3 / 13$ & $6 / 18$
\end{tabular}

over 4, developed a rising titre, while twenty out of thirty-six without previous antibody did so. It was concluded that antibody responses to infection did occur but not in every volunteer, and that responses were more frequent in those given large doses of virus and in those who already possessed antibody.

It was thought that antibody might protect against infection. Spickard et al. (1963), using 3000 TCD 50 of virus, found such an effect only when antibody levels estimated by the haemagglutination inhibition test were equal to or greater than 40. Table 6 shows that when a small dose of virus was given only two out of fourteen volunteers who were successfully infected had antibody to a titre of 4 or more, while four out of six who resisted infection had antibody. When larger doses of virus, i.e. 750 TCD 50, were given all the volunteers were infected but none had a titre as high as 40 . Similar results were obtained here earlier by Parsons et al. (1960). Spikard et al. observed six subjects with antibody levels comparable with ours who became infected, but whose illnesses appeared milder than those of subjects without antibody. In our studies thirty-seven volunteers without antibody became infected and developed colds, $62 \%$ mild, $32 \%$ moderate and $6 \%$ severe, while the percentage figures for seventeen with antibody were 60,25 and $15 \%$. It was concluded that antibody did protect volunteers against infection with small doses of virus but did not ameliorate the illness if they were infected with large doses. 
This was supported by further experiments in which volunteers were challenged on more than one occasion at intervals of 6 months or more. The results of these experiments are shown in Table 7. Volunteers A-D were all infected on the first occasion and resisted re-infection with 8 TCD 50 of virus. Volunteers $\mathrm{E}$ and F first

\section{Table 7. Immunity to challenge after inoculation}

\begin{tabular}{|c|c|c|c|c|c|}
\hline \multirow[b]{2}{*}{ Name } & & \multicolumn{4}{|c|}{ First exposure } \\
\hline & $\begin{array}{c}\text { H.I. } \\
\text { titre } \\
\text { before }\end{array}$ & TCD 50 & Cold & $\begin{array}{c}\text { Virus } \\
\text { recovered }\end{array}$ & $\begin{array}{l}\text { H.I. } \\
\text { titre } \\
\text { after }\end{array}$ \\
\hline A & 6 & 750 & + & + & 48 \\
\hline B & 8 & 750 & $\mathbf{0}$ & + & 8 \\
\hline $\mathrm{C}$ & $<4$ & 750 & 0 & + & 32 \\
\hline D & $<4$ & 750 & + & + & 16 \\
\hline $\mathbf{E}$ & 4 & $160^{*}$ & 0 & 0 & 4 \\
\hline $\mathbf{F}$ & $<4$ & 160 & 0 & 0 & $<4$ \\
\hline$G$ & $<4$ & 2500 & + & + & 4 \\
\hline
\end{tabular}

\begin{tabular}{|c|c|c|c|c|c|c|}
\hline \multicolumn{7}{|c|}{ Necona Oxposura } \\
\hline Name & $\begin{array}{l}\text { Interval } \\
\text { months }\end{array}$ & $\begin{array}{l}\text { H.I. } \\
\text { titre } \\
\text { before }\end{array}$ & Dose & Cold & $\begin{array}{c}\text { Virus } \\
\text { recovered }\end{array}$ & $\begin{array}{l}\text { H.I. } \\
\text { titre } \\
\text { after }\end{array}$ \\
\hline A & 12 & 32 & 8 & 0 & 0 & 32 \\
\hline B & 12 & 8 & 8 & 0 & 0 & 8 \\
\hline $\mathrm{C}$ & 6 & 8 & 8 & 0 & 0 & 8 \\
\hline D & 6 & 8 & 8 & 0 & 0 & 8 \\
\hline $\mathrm{E}$ & 6 & 4 & 8 & 0 & 0 & 4 \\
\hline $\mathbf{F}$ & 6 & $<4$ & 8 & + & + & 8 \\
\hline G & 10 & $<4$ & 8 & 0 & + & $<4$ \\
\hline \multicolumn{7}{|c|}{ Third exposure } \\
\hline Name & $\begin{array}{c}\text { Interval } \\
\text { months }\end{array}$ & $\begin{array}{c}\text { H.I. } \\
\text { titre } \\
\text { before }\end{array}$ & Dose & Cold & $\begin{array}{c}\text { Virus } \\
\text { recovered }\end{array}$ & $\begin{array}{l}\text { H.I. } \\
\text { titre } \\
\text { after }\end{array}$ \\
\hline A & - & - & - & - & - & - \\
\hline B & - & - & - & - & - & - \\
\hline $\mathrm{C}$ & - & - & - & - & - & - \\
\hline D & - & - & - & - & - & - \\
\hline $\mathrm{E}$ & 6 & $<4$ & 8 & 0 & + & 8 \\
\hline $\mathbf{F}$ & 6 & $<4$ & 8 & 0 & + & $<4$ \\
\hline G & - & - & - & - & - & - \\
\hline
\end{tabular}

received virus on the pharynx and were not infected; thereafter they were bothsuccessfully infected, one of them on two successive occasions, but $F$ showed no rise of antibody or any symptoms. Volunteer G developed an insignificant antibody response after infection with a large dose of unpassaged virus and was successfully reinfected, also without rise of antibody or symptoms. These experiments show that if there is an antibody response to infection with coxsackievirus A21 immunity to reinfection usually, but not invariably, develops, and that reinfection with the virus is also possible. 


\section{The shedding of virus by volunteers}

Colds were induced in volunteers by administering to the nasal septum 30 TCD 50 of virus unpassaged in tissue cultures. When symptoms of a cold developed the volunteers carried out the following manoeuvres:

(a) They coughed deeply into a large plastic bag, $120 \times 60 \mathrm{~cm}$.

(b) They talked for $5 \mathrm{~min}$. into a small plastic bag, $33 \times 19 \mathrm{~cm}$.

(c) They blew the nose vigorously three times with the head in a large plastic bag as in $(a)$. The handkerchief was a $27 \times 27 \mathrm{~cm}$. square of cotton and was held through the wall of the plastic bag with the hand outside.

(d) They snorted out ten times with the head in a large bag-it was found in control experiments that this dispersed spores from the nose in a similar fashion to an uninhibited sneeze which many volunteers were unable to produce with the head in the bag.

\section{Table 8. Dispersal of virus by volunteers with colds}

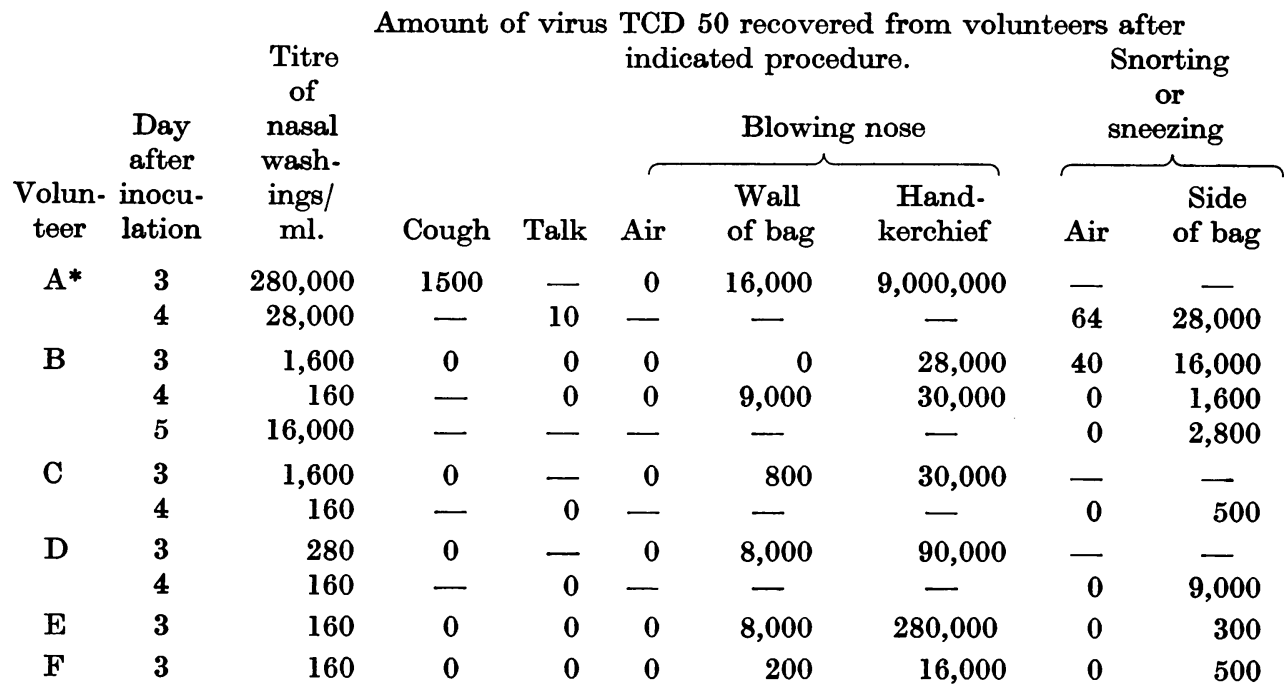

* In order of peak concentration of virus.

The air was sampled with a preimpinger containing culture medium and the wall of the polythene bag into which the volunteer talked, sneezed, etc., was washed with culture medium.

The assay of nasal secretion is given as particles per ml. Virus recovered is given as number of particles.

Virus was recovered from the air of the bags with a preimpinger sampler; the wall of the bag was washed with $100 \mathrm{ml}$. medium and the handkerchief was shaken in a flask with $100 \mathrm{ml}$. of medium. The washings and sampler fluid were assayed for virus. The results are shown in Table 8. This indicates that no virus was shed on coughing or talking except by one volunteer whose nasal secretions contained an exceptionally high concentration of virus. All six volunteers excreted virus on blowing the nose, and the virus could be recovered from the handkerchief and bag but none could be recovered from the air. Finally, after snorting, virus was recovered in relatively large amounts in the washings of the bag and twice from 
the air also. It was concluded that only a sneeze or snort unmuffled by a handkerchief produced detectable amounts of airborne virus under the experimental conditions used. More important than this, it appeared that one volunteer was probably far more efficient than any of the others as a potential spreader of infection, and this was apparently due to the high concentration of virus in the respiratory secretions; the cold from which she suffered was graded as mild and was not more severe than other illnesses in which virus was not shed. We noted that the amount of virus expelled into the handkerchief and bag was more than expected from the titre of the nasal washings (Table 8). This might have occurred if the nasal washings contained about $1 \%$ of nasal secretion rather than the $10 \%$ assumed earlier.
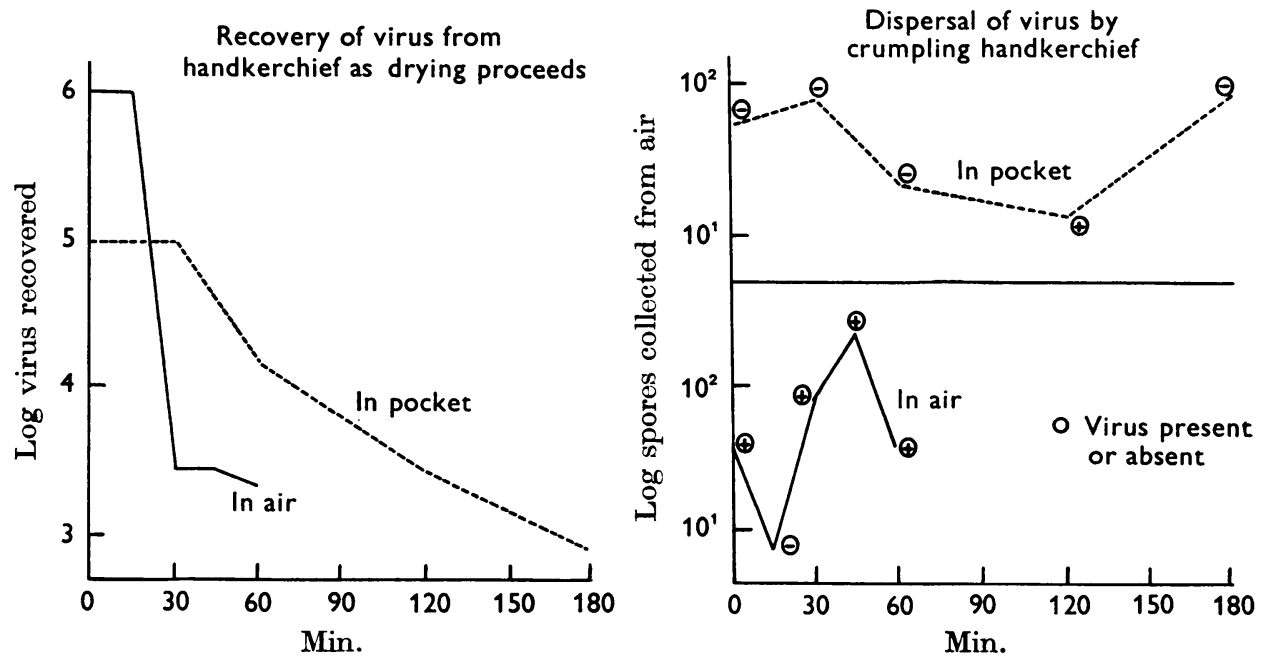

Fig. 4. The fate of coxsackievirus A 21 in tissue culture fluid containing $2 \%$ bovine plasma albumen added to a handkerchief. The virus died off as the fabric dried, either in air or in a pocket. $10^{6.45}$ spores were added with the virus as a tracer. Very few of these could be recovered by vigorously crumpling and shaking the handkerchief inside a plastic bag and sampling the air with a preimpinger. However, traces of virus were recovered though in amounts too small to titrate.

We wondered if virus sneezed into a handkerchief or clothing might subsequently become airborne, and one of the experiments performed to test this hypothesis is summarized in Fig. 4. Virus produced in tissue culture $\left(10^{7.5}\right.$ TCD 50/ml.) was mixed with spores and a few drops with a total volume of $0.02 \mathrm{ml}$. were placed on each of a series of new cotton handkerchiefs. These were then allowed to dry either by hanging on a wire in the laboratory (temperature about $70^{\circ} \mathrm{F}$., R.H. about $60 \%$ ) or by being folded and placed in the coat pocket of a laboratory worker. At intervals handkerchiefs were assayed for virus and spores, or crumpled and shaken by hand for $45 \mathrm{sec}$. in a plastic bag, which was then evacuated through a preimpinger in the usual way. The results (Fig. 4) show that virus infectivity was rapidly lost, although the spores could be recovered from the fabric almost quantitatively. A few spores and traces of virus were recovered from the air. The experiment was repeated using nasal secretion containing a fairly high titre $\left(10^{4 \cdot 5} \mathrm{TCD} 50 / \mathrm{ml}\right.$.) of 
virus which had been collected as it dropped from the volunteer's nose and had not been diluted with saline or supplemented with any preservative. Infectivity was lost equally rapidly, and few spores and no virus were recovered from the air.

We noted that there was not a strict parallel between the titre of virus in a nasal secretion, and the amount which the patient sneezed or blew out. We therefore placed $0.05 \mathrm{ml}$. volumes of a tracer suspension of $B$. mycoides spores in the anterior nasal septum of volunteers without colds and studied the dispersal of the spores when they blew the nose 2 min. later. The results summarized in Table 9 show what a variable effect a nose-blow had. Most of what was expelled was trapped in the handkerchief, but up to $35 \%$ might be found in drops attached to the side of the bag. In some cases no spores were recovered from the air while in others there were appreciable numbers. The original data suggested that there was a tendency for certain individuals rather than others to produce airborne spores.

Table 9. Summary of twelve experiments with six subjects on the expulsion of spores by blowing the nose

\begin{tabular}{|c|c|c|c|c|}
\hline & \multicolumn{2}{|c|}{ Absolute values } & \multicolumn{2}{|c|}{$\begin{array}{c}\text { Proportion of } \\
\text { total expelled }(\%)\end{array}$} \\
\hline & Mean & Range & Mean & Range \\
\hline Total spores expelled & $14,000,000$ & $1,600,000-34,000,000$ & 100 & - \\
\hline No. trapped in handkerchief & $13,000,000$ & $1,600,000-32,000,000$ & 93 & $66-99 \cdot 7$ \\
\hline No. trapped in impinger & 790 & $0-2,900$ & 0.006 & $0-0 \cdot 13$ \\
\hline No. trapped in preimpinger & 290 & $0-1,600$ & 0.002 & $0-0.09$ \\
\hline No. trapped on side of bag & 910,000 & $400-440,000$ & $6 \cdot 5$ & $0 \cdot 004-35$ \\
\hline
\end{tabular}

It also seemed possible that the quantity of virus secreted might continually be changing. Three washings were therefore taken from four volunteers at intervals of from $5 \mathrm{~min}$. to $3 \mathrm{hr}$. Virus was found in all specimens. In one case a second nasal washing taken $5 \mathrm{~min}$. after the first showed a 60-fold lower titre, but apart from this instance the titre of washings taken at this or longer intervals fell within a tenfold range, and did not show a downward trend. It was impossible to decide whether the variation was due to variation in the amount of secretion removed or in the concentration of virus, or to the error of the titrations. It was concluded that virus was being produced in a fairly steady stream and that more virus might be expelled into a handkerchief than could be recovered from a nasal washing.

\section{Transmission of virus from one volunteer to another}

Although very little virus was shed from a volunteer at each sneeze it was possible that another volunteer who was living with him and inhaling air throughout the course of a cold might pick up a live virus particle and become infected. Attempts were therefore made to transmit infection from volunteer to volunteer.

In the successful attempts 'donor' volunteers were inoculated shortly after arriving at the Unit and lived with an uninoculated partner for the next 9 days. Nasal washings were collected on each day from each partner. Table 10 shows that tissue-culture-passed virus and unpassaged virus were transmitted and that about one in five volunteers exposed became infected. Nevertheless, it was not possible 
to transmit infection to eleven volunteers each of whom inhaled the air from a plastic bag into which an infected volunteer had just sneezed or snorted. This was reasonable since virus was recovered only from the walls of the bag and not from the air (see above). Unfortunately, no volunteers were exposed to the one donor subject who apparently transmitted a cold to his partner. He was excluded from this experiment because his cold seemed to be so mild!

\section{Table 10. Transmission of coxsackievirus $A 21$ between volunteers with various types of contact}

$\begin{array}{cc}\begin{array}{c}\text { Dose } \\ \text { given }\end{array} & \begin{array}{c}\text { No. } \\ \text { infected }\end{array} \\ 750^{*} & 12 / 12 \\ 30 & 6 / 6 \\ 30 & 6 / 6 \\ & \\ 0 \cdot 8 & 2 / 6 \\ 0 \cdot 8 & 2 / 6\end{array}$

The three infected recipients had antibody titres of 4 or less as did twenty-eight of the thirty-six uninfected recipients.

* The 750 TCD 50 were of tissue-culture-passed virus. The other doses were of virus passed only in man.

It seemed unlikely that volunteers would be infected in nature with as much as 30 TCD 50 of virus; also coxsackievirus tends to spread under conditions of communal living. We therefore infected two volunteers with a small dose of virus $(0.8$ TCD 50). They had very mild symptoms but spent $1 \mathrm{hr}$. twice a day playing card games with eight other volunteers in a room with closed windows and doors and were encouraged to snort or sneeze several times during each session. No virus was transmitted.

It was concluded that virus could be transmitted from one volunteer to another by regular personal contact, but that the rate of transmission was too low to support an epidemic.

\section{DISCUSSION}

These experiments were designed to test experimentally various common assumptions about the way colds spread by making semiquantitative measurements of virus concentration and clinical response in a convenient model disease. Having considered these new data our present conception of the spread of colds due to this virus is as follows:

Because of the high concentration of virus in nasal secretion it seems that the nose is the most likely origin of infectious virus, although rare individuals with virus in the saliva might disperse it on talking. As earlier tracer experiments led us to expect, we now have evidence that virus is expelled most easily by sneezing or blowing the nose. However, the experiments on infection of volunteers indicate that the only virus of epidemiological importance is that which reaches the nasal 
mucous membrane, since we have shown earlier that relatively few infectious particles were likely to be taken up by the conjunctiva (Buckland \& Tyrrell, 1964). Our experiments there described, using spore tracers and a variety of sampling methods, together with the present analysis of virus sneezed into polythene bags, indicate that only a tiny fraction of what is sneezed out is in the form of infectious airborne droplets. Furthermore, most of the virus which is caught in the handkerchief or falls on to the clothes or floor becomes inactivated, unlike those bacteria which resist drying and can therefore be readily resuspended in small particles after they have dried on to fabrics (Dumbell \& Lovelock, 1949). As virus is very rapidly inactivated in droplets under $4 \mu$ in size and fairly rapidly inactivated in droplets larger than this, which in any case will tend to settle out, it is probable that there is a high risk of inhaling an infectious particle only if the recipient is near a cold sufferer who has just sneezed. Fine droplets are unlikely to be important; they might travel far but would probably be non-infectious when inhaled and in any case would be trapped in the lower respiratory tract where they would presumably cause bronchitis or a similar disease (Knight et al. 1963): such is not in fact seen in natural infection with this virus.

At first sight our laboratory data may be suspect because they suggest that viruses of this sort are unlikely to spread and that in fact we could not have maintained the chain of infection required in order to produce an epidemic; after all twenty experimental infections were followed by only three secondary ones and one clinically recognizable cold. The average secondary attack rate based on clinical observations of colds is about 1 in 5 (Lidwell \& Sommerville, 1951), although less than half the adult population develops colds after infection with most cold-producing viruses (Andrewes, 1948; Jackson et al. 1960). On the other hand, when we planned our experiments we did not realize how variable was the excretion of virus by volunteers. It is possible that only one of every ten subjects infected is really likely to pass this infection on, and in this case it would be necessary to infect a group of about ten subjects and expose them all to each of another group of ten or more susceptibles in order to have a chance of propagating the infection continuously from man to man. Furthermore, the living conditions were very spacious. Even though a human being samples around $10 \mathrm{l}$. of air per minute throughout the day it is obvious that in large well-ventilated rooms the probability of inhaling a virus particle was much lower than in smaller ill-ventilated ones. In fact, our data may well explain adequately why this virus seems to spread successfully only under the conditions of the barrack room or in crowded oriental cities (Fukumi, Nishikawa, Sonoguchi \& Shimizu, 1962).

The clinical picture observed in volunteers is identical with that observed in our own and other trials in which large doses of tissue-culture-passed virus were given to volunteers (Parsons et al. 1960; Spickard et al. 1963; Patel, Buthala \& Walker, 1964). However, it is important to note that a similar disease was induced in the present studies by small doses of virus which had not been passed in tissue cultures. In addition, since the disease was indistinguishable from that observed in the field (McDonald, Miller, Zuckerman \& Pereira, 1962; Johnson et al. 1962; Forsyth, Bloom, Johnson \& Chanock, 1963) we believe that our experimental results may 
be assumed to apply to the spread of virus in the field. The concept that one patient who appears on clinical examination to be like many others may be a particularly potent 'spreader' of infection is not new. Hamburger, Green \& Hamburger (1945) showed that nasal carriers of streptococci shed far more organisms than those who carried them elsewhere in the respiratory tract. The experiments of Lovelock et al. (1952) with an undefined cold-producing agent gave results which were in many ways similar to those in the present trial; in particular they concluded that it was very difficult to transmit colds from volunteer to volunteer, that virus produced colds only if introduced into the nasal cavity and that virus was probably transmitted from infected children in the form of 'short-range' airborne droplets.

It is likely that certain findings in this series of experiments, such as the proportion of virus expelled by sneezing, will apply also to colds produced by other viruses, and we wonder whether it will be possible in future experiments using this approach to find reasons for the apparently more efficient spread of viruses such as influenza or parainfluenza. It might also be possible to define one or other link in the epidemiological chain which is readily modified by seasonal changes. Much further work is needed on these problems.

\section{SUMMARY}

The amount of virus in nasal and other secretions after infection with coxsackievirus A 21 has been measured daily in ten volunteers. Most virus was found in nasal secretion, less in throat secretion and small amounts were found intermittently in the saliva and faeces.

Virus administered as small drops or on a swab was more infectious for man if put on to the nasal mucosa than on to the throat or outside the nose. It was also infectious by the conjunctival route.

Virus was sprayed in droplets of about the same size range as those found in a natural sneeze. Virus survived better in larger $(>4 \mu)$ than in smaller droplets. About one tissue culture infectious dose of virus in such droplets also infected volunteers.

The symptoms produced by these experimental infections have been analysed. The disease produced was largely independent of the dosage and route of infection. Those with pre-existing antibody resisted infection better than those with no antibody. Antibody rises were detected in about two-thirds of infected volunteers.

Volunteers with colds shed virus in large drops on sneezing, or into the handkerchief on blowing the nose, but virus was recovered from the air only after simulated sneezes by volunteers with high concentrations of virus in their nasal secretions. Virus died off rapidly on fabric at room temperature and humidity, and was only resuspended as airborne droplets when large doses such as $0.02 \mathrm{ml}$. of virus of high titre ( $10^{7 \cdot 5} \mathrm{TCD} 50 / \mathrm{ml}$.) were used.

Infection was transmitted from an infected volunteer to an uninfected partner living in the same flat in three out of twenty tests. Infection was not transmitted in experiments when volunteers mixed for a few hours with subjects with colds, or inhaled air into which a subject with a cold had just sneezed. 
We wish to thank the volunteers for their willing help, Miss E. M. Bullock for help with clinical observations and Miss P. Ball for technical assistance. The air sampling equipment was supplied by the Microbiological Research Establishment, Porton, Wilts.

\section{REFERENCES}

Andrewes, C. H. (1948). Cantor Lecture. The common cold. Jl. R. Soc. Arts, 96, 200.

Bell, J. A., Ward, T. G., Huebner, R. J., Rowe, W. P., Suskind, R. G. \& Paffenbarger, R. S. (1956). Studies of adenoviruses (APC) in Volunteers. Am. J. publ. Hlth, 46, 1130.

Brown, P. K. \& Tyrrell, D. A. J. (1964). Experiments on the sensitivity of strains of human fibroblasts to infection with rhinoviruses. Br.J. exp. Path. 45, 571.

Buckland, F. E. \& Tyrrell, D. A. J. (1964). Experiments on the spread of colds. 1. Laboratory studies on the dispersal of nasal secretion. J. Hyg., Camb., 62, 365.

Dumbeli, K. R. \& Lovelock, J. E. (1949). Handkerchiefs in the transfer of respiratory infections. Lancet, i, 777.

Forsyth, B. R., Bloom, H. H., Johnson, K. M. \& Chanock, R. M. (1963). Patterns of illness in rhinovirus infections of military personnel. New Engl. J. Med. 269, 602.

Fukumi, H., Nishikawa, F., Sonoguchi, T. \& Shimizu, T. (1962). Further studies on epidemiology of Coe virus infection. Jap. J. med. Sci. Biol. 15, 145.

Hamburger, M., Green, M. J. \& Hamburger, V. G. (1945). The problem of the 'dangerous carrier' of haemolytic streptococci. J. infect. Dis. 77, 68, 96.

Huebner, R. J., Bell, J. A., Rowe, W. P., Ward, T. G., Suskind, R. G., Hartley, J. W. \& Paffenbarger, R. S. (1955). Studies of adenoidal pharyngeal conjunctival vaccines in volunteers. J. Am. med. Ass. 159, 986.

Jackson, G. G., Dowling, H. F., Anderson, T. O., Riff, L., Saporta, J. \& Turck, M. (1960). The susceptibility and immunity to common upper respiratory viral infections-the common cold. Ann. intern. Med. 53, 719.

Johnson, K. M., Bloom, H. H., Mufson, M. A. \& Chanock, R. M. (1962). Acute respiratory disease associated with Coxsackie-A 21 virus infection. J. Am. med. Ass. 179, 112.

Knight, V., Gerone, P. J., Griffith, R. B., Couch, T. R., Johnson, K. M., Lang, D. J. Evans, H. E., Spickard, A. \& Kasel, J. A. (1963). Studies in volunteers with respiratory viral agents. Am. Rev. resp. Dis. 88, (2), 135.

Lennette, E. H., Fox, V. L., Schmidt, N. J. \& Culver, J. O. (1958). The Coe virus. An apparently new virus recovered from patients with mild respiratory disease. Am. J. Hyg. 68, 272.

Lidwell, O. M. \& Sommerville, T. (1951). Observations on the incidence and distribution of the common cold in a rural community during 1948 and 1949. J. Hyg., Camb., 49, 365.

Lovelock, J. E., Porterfield, J. S., Roden, A. T., Sommerville, T. \& Andrewes, C. H. (1952). Further studies on the natural transmission of the common cold. Lancet, ii, 657.

McDonald, J. C., Miller, D. L., Zuckerman, A. J. \& Pereira, M. S. (1962). Coe (Coxsackie A 21) virus, para-influenza virus and other respiratory virus infections in the R.A.F., 1958-60. J. Hyg., Camb., 60, 235.

Negus, Sir V. (1958). The Comparative Anatomy and Physiology of the Nose and para-nasal sinuses. Edinburgh and London: Livingstone.

Parsons, R., Bynoe, M. L., Pereira, M. S. \& Tyrrell, D. A. J. (1960). Inoculation of human volunteers with strains of Coe virus isolated in Britain. Br. med. J. i, 1776.

Patel, N., Buthala, D. A. \& Walker, J.S. (1964). Controlled studies of coxsackie A 21 virus in volunteers. J. infect. Dis. 114, 87.

Pereira, M. S. \& Pereira, H. G. (1959). Coe virus-properties and prevalence in Great Britain. Lancet, ii, 539.

Reed, L. J. \& Muench, H. (1938). Simple method of estimating 50 per cent endpoints. Am. J. Hyg. 27, 493.

Spickard, A., Evans, H., Knight, V. \& Johnson, K. (1963). Acute respiratory disease in normal volunteers associated with Coxsackie A 21 viral infection. III. Response to nasopharyngeal and enteric inocululation. J. clin. Invest. 42, 840.

TAKÁtSY, G. Y. (1955). The use of spiral loops in serological and virological micromethods. Acta microbiol. hung. 3, 191. 